\section{Rosely Sichieri'}

Erly Catarina de Moura",,II

Departamento de Epidemiologia. Universidade do Estado do Rio de Janeiro. Rio de Janeiro, RJ, Brasil

" Núcleo de Pesquisas Epidemiológicas em Nutrição e Saúde. Universidade Federal de São Paulo. São Paulo, SP, Brasil

III Coordenação Geral de Doenças Crônicas não Transmissíveis. Secretaria de Vigilância em Saúde. Ministério da Saúde. Brasília, DF, Brasil

\section{Correspondence:}

Rosely Sichieri

Universidade do Estado do Rio de Janeiro

R. São Francisco Xavier 524 - Maracanã

20550-900 Rio de Janeiro, RJ, Brasil

E-mail: sichieri@ims.uerj.br

\section{A multilevel analysis of variations in body mass index among adults, Brazil, 2006}

\begin{abstract}
OBJECTIVE: To analyze the variation in body mass index (BMI) among adults according to individual factors and environmental characteristics of their city of residence.

METHODS: Data generated in 2006 by the Vigilancia de Fatores de Risco e Proteção para Doenças Crônicas por Inquérito Telefônico (VIGITEL Telephone-based Surveillance of Risk and Protective Factors for Chronic Diseases) system. This survey is based on telephone interviews carried out among probabilistic samples of the population of adults aged $\geq 18$ years from the 26 Brazilian state capitals and Federal District. Analysis of associated factors included individual socioeconomic and demographic variables and environmental variables pertaining to the city of residence of the 49,395 VIGITEL subjects. Food intake was evaluated based on a "healthy diet" score and on "five-a-day" fruit and vegetable intake. Physical activity was evaluated based on frequency and duration of exercise and presence of a place in which to perform physical activity. Associations were tested using multilevel linear models $(\mathrm{p}<0.05)$.
\end{abstract}

RESULTS: Associations between BMI and individual explanatory variables differed according to sex. Schooling was positively associated with BMI among men, and negatively among women. Five-a-day fruit and vegetable intake was positively associated with BMI among men. In both sexes, presence of a place for physical activity was negatively associated with BMI.

CONCLUSIONS: Mean BMI differed substantially among Brazilian capitals; however little of this variation could be explained by presence of a place for physical activity or by socioeconomic and diet-related variables.

DESCRIPTORS: Body Mass Index. Risk Factors. Socioeconomic Factors. Gender and Health. Chronic Disease, prevention \& control. Health Surveys. Brazil. Telephone interview. 


\section{INTRODUCTION}

The increasing prevalence of obesity and its consequences - such as diabetes mellitus, cardiovascular disease, and certain types of cancer, in addition to treatment costs, ${ }^{16}$ - has led to a recurrent scrutiny of the factors associated with this condition. This scenario is common to developed countries and to Brazil. ${ }^{14}$ Even though environmental factors - such as excess food intake and insufficient physical activity - are widely regarded as the major determinants of obesity, these variables are difficult to measure. Consequently, successful treatments for obesity, when adequate, are able to reduce a patient's body weight by approximately $10 \%$, with virtually all patients regaining the weight lost during treatment after cessation. ${ }^{10}$

In most studies, factors classified as "environmental" actually correspond to behavioral characteristics of the individual, and there is little evidence that characteristics of the actual environment are able to modify the course of an obesity epidemic, as concluded by Brug et $\mathrm{al}^{2}$

On the other hand, there is evidence that socioeconomic factors can be associated with obesity. Income, schooling, and race have been intensely studied, especially considering the complexity of such relationships. ${ }^{5,13}$ Environmental and socioeconomic factors may explain changes in the course of an epidemic, since individual characteristics play a role in the development of obesity and living in a poor environment can contribute towards weight gain and maintenance. Fruit and vegetables (F\&V), considered as protective against obesity, can weigh on the budget of poorer families. ${ }^{3}$ Though F\&V availability is lower in these settings, facilitating their acquisition can lead to higher intake frequency. ${ }^{8}$

Strategies for preventing obesity also seem to depend on understanding environmental factors. There is a consensus, especially with regard to measures targeting the younger population, that centering initiatives on the individual may not be the most adequate strategy. Modern society is highly obesogenic, and a multitude of factors can lead to the failure of individual preventative measures. For adolescents, being part of a group signifies adopting a certain pattern of consumption, which extends to dietary choices as well. ${ }^{17}$ It is therefore fundamental to define the obesogenic environment and to understand how the absence of parks, recreation facilities, and places for purchasing healthy foods can promote weight gain., ${ }^{2,8,11}$

Few studies have concomitantly explored the role of socioeconomic factors acting both at the individual and environmental levels. The aim of the present study was to analyze the variation in body mass in- dex (BMI) among adults according to individual factors and environmental characteristics of their cities of residence.

\section{METHODS}

We carried out a cross-sectional study of data generated by the Telephone-based Surveillance of Risk and Protective Factors for Chronic Diseases (VIGITEL) survey. This survey included 54,369 telephone interviews carried out in 2006 on probabilistic samples of the adult population with access to a fixed telephone line in the 26 Brazilian state capitals and Federal District. Estimates were weighted considering differences between the sociodemographic composition of each sample and that of the entire adult population of the city, data on the latter being obtained from the 2000 population census. Further methodological details can be found in Moura et al. ${ }^{15}$

Individual variables investigated included socioeconomic characteristics, smoking (yes/no), food intake, and physical activity. Socioeconomic variables included sex, self-reported skin color (classified as white, mixed, or black), cell-phone ownership (yes/ no) and number of rooms in the household.

In the present study, the food consumption patterns of 49,395 subjects was explored using the self-reported frequency of intake of fruit, salads, other vegetables, beans, soft drinks, milk, and alcoholic beverages in six categories of increasing frequency: from 1 (never) to 6 (every day). Milk and soft drinks could be classified as light/diet. Intake of chicken with skin or meat with apparent fat (categories: 1- always eats; 2- removes skin or fat; 3 - does not eat) was also investigated. For analysis purposes, we defined a "healthy diet" score based on principal component analysis performed using SAS software version 9.1. Frequency of intake variables were combined with the milk and soft drinks variables and with intake of apparent fat. A negative (-) charge indicates that a variable is inversely associated with the factor, whereas a positive charge $(+)$ indicates a direct association. We used the first factor categorized into quartiles, and since values were similar for men and women, we used a single value for both sexes. The eigenvalue was 2.11 , and charges ranged from -0.14 for alcohol to +0.38 for frequency of fruit intake. Frequency of milk intake was excluded due to its weak correlation with the remaining variables.

A specific question with a dichotomous answer on the daily intake of five or more portions (five-a-day) of $\mathrm{F} \& \mathrm{~V}$ was also included in the analysis. 
Physical activity was explored by determining both its frequency (classified into four categories, from every day to once or twice a week) and duration (in six categories, from one to ten minutes to 60 minutes or longer).

Among the environmental variables of subject's the city of residence (city variables), we investigated the percentage of subjects per city consuming five or more portions of $\mathrm{F} \& \mathrm{~V}$ per day, the percentage of subjects who owned cell phones, mean schooling, mean number of rooms per household, and the percentage of positive answers regarding the availability of a place for performing physical activity.

We tested the association between BMI and individual or city variables using a multilevel linear regression model. Initially, we evaluated all individual in linear models, adjusted only for age (in years). All variables with p-values below 0.10 were kept in the final model. A similar procedure was employed for city variables.

Preliminary analysis consisted on determining how cities varied in relation to each other and then estimating whether clusters of cities with similar mean BMI remained different in analyses adjusted by the final model, which included all individual and city variables. We were thus able to determine how much of city variation could be explained by the investigated variables.

Since this is a telephone-based system, the term of free informed consent was replaced by verbal consent obtained during telephone contact with the subject. The VIGITEL system was approved by the Research Ethics Committee for Human Subjects of the Brazilian Ministry of Health.

\section{RESULTS}

Table 1 presents the mean and median BMI for men and women according to city of residence. Differences among men were statistically significant for fewer cities than differences among women, and the variation in magnitude was also greater among women (Table 2). However, BMI was always lower among women than men. Differences between men and women tended to disappear as BMI increased (Figure).

Clustering of cities that did not differ significantly in terms of BMI $(p<0.05)$ generated six clusters (Table 2). This clustering was not associated with the healthy diet score or five-a-day F\&V intake, or with physical exercising in leisure (data not shown). Frequency of physical exercise was lowest in São Luis (the city with lowest BMI): $38.7 \%$ vs. $46.7 \%$ in cities that did not differ from the overall mean. The highest frequency of subjects in the healthiest score quartile and of five-a-day F\&V (22\% and $9 \%$, respectively), was found in the cluster of cities with a difference in mean $\mathrm{BMI}$ of +0.03 .

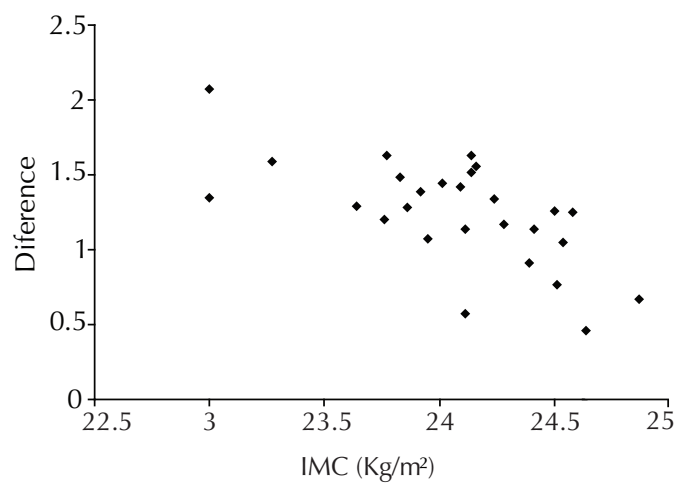

Figure. Age-adjusted difference in body mass index between men and women, plotted against the mean value for women, according to city of residence. Brazil, 2006. Note: Values are weighted to adjust the sociodemographic distribution of the VIGITEL sample to that of the adult population of each city according to the 2000 Demographic Census.

The first stage of the multilevel analysis estimated the specific contribution of individual and city variables to BMI variance. For both men and women, less than $1 \%$ of variance could be attributed to environmental characteristics of the city of residence.

Bivariate analysis of individual variables showed that associations were different among men and women (Table 3). Schooling was positively associated with BMI among men and negatively among women; race was significantly associated with BMI only among women, black and mixed women having higher mean BMI. Higher healthy diet scores were found to be protective among women, but greater five-a-day $\mathrm{F} \& \mathrm{~V}$ intake was positively associated to BMI among men. Among city variables, there was a consistent negative association between BMI and availability of places for physical activity among both sexes.

After adjustment for all variables with $\mathrm{p}<0.10$ (Table 3 ), differences between clusters of cities in terms of mean BMI remained significant (Table 4). The determination coefficient (R2) showed that models including only women were able to explain $11 \%$ of total variance, vs. $5 \%$ for models including only men.

\section{DISCUSSION}

Although there is a discrepancy between Brazilian cities in terms of mean BMI, little of this variation could be explained by the environmental characteristics of these cities investigated in the present study. The system did not include other characteristics of the environment potentially associated with obesity, such as food supply and distribution, transportation networks, equity indicators, and cultural indicators, among others. 
Table 1. Number of subjects interviewed (n) and mean and median body mass index. ${ }^{a}$ Brazil, 2006. (N=49.395)

\begin{tabular}{|c|c|c|c|c|c|c|}
\hline \multirow{2}{*}{ City } & \multicolumn{3}{|c|}{ Men } & \multicolumn{3}{|c|}{ Women } \\
\hline & $\mathrm{n}$ & Mean & Median & $\mathrm{n}$ & Mean & Median \\
\hline Aracaju & 702 & 25.62 & 24.62 & 1118 & 24.03 & 23.31 \\
\hline Belém & 771 & 25.52 & 24.69 & 1039 & 23.76 & 22.94 \\
\hline Belo Horizonte & 754 & 24.98 & 24.45 & 1086 & 23.77 & 23.23 \\
\hline Boa Vista & 785 & 25.50 & 24.98 & 1026 & 24.24 & 23.44 \\
\hline Brasília & 781 & 25.00 & 24.62 & 1134 & 23.80 & 23.05 \\
\hline Campo Grande & 754 & 25.41 & 24.97 & 1078 & 24.54 & 23.67 \\
\hline Cuiabá & 807 & 25.78 & 25.25 & 1061 & 24.49 & 23.73 \\
\hline Curitiba & 757 & 25.58 & 25.00 & 1135 & 24.63 & 23.53 \\
\hline Florianópolis & 810 & 25.31 & 24.91 & 1092 & 24.04 & 22.99 \\
\hline Fortaleza & 750 & 25.45 & 24.84 & 1041 & 24.28 & 23.51 \\
\hline Goiânia & 753 & 24.83 & 24.59 & 1112 & 23.84 & 22.77 \\
\hline João Pessoa & 751 & 25.43 & 24.81 & 1047 & 24.43 & 23.56 \\
\hline Macapá & 802 & 25.55 & 24.82 & 1016 & 24.14 & 23.23 \\
\hline Maceió & 744 & 25.07 & 24.46 & 1039 & 24.10 & 23.34 \\
\hline Manaus & 822 & 25.67 & 25.21 & 978 & 24.66 & 23.53 \\
\hline Natal & 737 & 25.70 & 24.80 & 1062 & 24.51 & 23.73 \\
\hline Palmas & 860 & 24.98 & 24.49 & 1019 & 23.14 & 22.03 \\
\hline Porto Alegre & 713 & 25.79 & 25.34 & 1209 & 25.22 & 24.17 \\
\hline Porto Velho & 825 & 25.34 & 24.68 & 998 & 24.28 & 23.44 \\
\hline Recife & 712 & 25.12 & 24.62 & 1131 & 24.76 & 24.03 \\
\hline Rio Branco & 771 & 25.03 & 24.49 & 981 & 24.54 & 24.03 \\
\hline Rio de Janeiro & 720 & 25.70 & 25.38 & 1116 & 24.92 & 24.34 \\
\hline Salvador & 762 & 24.72 & 24.26 & 1022 & 24.10 & 23.63 \\
\hline São Luís & 744 & 24.20 & 24.06 & 1025 & 23.66 & 22.67 \\
\hline São Paulo & 763 & 25.29 & 24.68 & 1114 & 25.04 & 24.32 \\
\hline Teresina & 730 & 24.76 & 24.22 & 1026 & 23.58 & 22.81 \\
\hline Vitória & 742 & 25.19 & 24.62 & 1068 & 23.91 & 23.14 \\
\hline Total & 20.622 & 25.31 & 24.77 & 28.773 & 24.55 & 23.78 \\
\hline
\end{tabular}

${ }^{\text {a }}$ Values are weighted to adjust the sociodemographic distribution of the VIGITEL sample to that of the adult population of each city according to the 2000 Demographic Census.

The finding that the variability in BMI is centered essentially on the individual seems to reflect the fact that intra-city variation within each capitals was found to be greater than inter-city variation among the capitals, regardless of the city's level of development. Moreover, restricting participation to the population with access to a fixed telephone line excluded the poorest sector of the population, thus minimizing differences between cities, despite the sample weighting procedures employed to reduce such bias.

According to Levy et al, ${ }^{11}$ in a study of household availability data, only very low-income households show decreased intake of fats and soft drinks, two key foods associated with promotion of obesity. In other words, the obesogenic environment in Brazil is likely to include the vast majority of the population, with the exception of the very poor. Thus, only individuals protected by endogenous factors or strongly engaged in active weight control would succeed in maintaining adequate weight. Along those lines, adolescents with adequate BMI were found to have similar or worse dietary and exercise-related habits than their overweight counterparts. ${ }^{1}$

Our results are similar to those of multilevel studies with adolescents carried out in the United States ${ }^{17}$ and Canada, ${ }^{9}$ in which individual characteristics such as race, household socioeconomic level, social capital, hours spent watching television, computer use, and physical activity accounted for most of the variation in obesity. Neighborhood poverty explained $18 \%$ of this variation. ${ }^{17}$ Such high explanatory capacity reflects the high prevalence o obesity among American 
Table 2. Differences in mean body mass index after logarithmic transformation and adjustment for age. ${ }^{\mathbf{a}}$ Brazil, 2006. $(\mathrm{N}=49,395)$

\begin{tabular}{|c|c|c|c|c|c|}
\hline \multirow{2}{*}{ Sex } & \multicolumn{5}{|c|}{ City $^{\mathbf{a}}$} \\
\hline & $<-0.01$ & +0.01 & 0.02 & 0.03 & 0.04 \\
\hline Men & São Luís & $\begin{array}{c}\text { Belém, Campo } \\
\text { Grande, Curitiba, } \\
\text { Fortaleza }\end{array}$ & $\begin{array}{c}\text { Cuiabá, Macapá, } \\
\text { Natal, Porto } \\
\text { Alegre, Porto } \\
\text { Velho }\end{array}$ & Manaus & - \\
\hline Women & São Luís & $\begin{array}{c}\text { Belém, Fortaleza, } \\
\text { João Pessoa, Salvador }\end{array}$ & $\begin{array}{c}\text { Campo Grande, } \\
\text { Cuiabá, Natal, } \\
\text { Porto Alegre, } \\
\text { Recife }\end{array}$ & $\begin{array}{c}\text { Boa Vista, Curitiba, } \\
\text { Macapá, Porto } \\
\text { Velho, Rio de } \\
\text { Janeiro, São Paulo }\end{array}$ & $\begin{array}{c}\text { Manaus, Rio } \\
\text { Branco }\end{array}$ \\
\hline
\end{tabular}

a Values are weighted to adjust the sociodemographic distribution of the VIGITEL sample to that of the adult population of each city according to the 2000 Demographic Census.

adolescents, which ranges from $10 \%$ to $18 \% \cdot{ }^{17}$ In the present study, it should be noted that the environmental variables investigated in the cities are strongly correlated with the individual variables. Furthermore, the only variable that effectively measured the availability places suited for physical activity in the urban environment was consistently associated with lower BMI among both men and women.

Differences related to sex were identified in a multilevel study carried out in Canada, ${ }^{12}$ where men from richer neighborhoods had higher BMI than those living in poorer areas, whereas the opposite was true for women, even after adjustment for individual variables. These authors recommend that specific obesity reduction programs be developed for each sex. ${ }^{12}$
In the present study, the mean number of rooms per household in each city was associated with BMI among women, more rooms being associated with lower BMI. Such association was not observed among men. Lifestyle factors traditionally investigated may not be able to explain this gender difference. Cultural influences that encourage women to remain thin could lead to cycles of dieting/weight gain that would not occur among men. However, as prevalence of overweight in the population increases, the difference between men and women decreases, that is, if women are initially more susceptible to becoming obese, such gender differences tend to disappear as the environment becomes more obesogenic.

Differences between men and women in terms of the association between dietary pattern and BMI suggest

Table 3. Age-adjusted linear regression coefficient ( $\beta$ ), (values of body mass index log transformed) according to individual variables and environmental characteristics of the city of residence. ${ }^{a}$ Brazil, 2006. ( $\left.N=49.395\right)$

\begin{tabular}{|c|c|c|c|c|}
\hline \multirow{2}{*}{ Individual variable } & \multicolumn{2}{|c|}{ Men } & \multicolumn{2}{|c|}{ Women } \\
\hline & $\beta$ & $P$ & $\beta$ & $P$ \\
\hline \multicolumn{5}{|l|}{ Exercise } \\
\hline Frequency & -0.0007 & 0.53 & -0.0023 & 0.02 \\
\hline Duration & -0.0005 & 0.54 & 0.0002 & 0.82 \\
\hline Schooling (degree) & 0.006 & $<0.0001$ & -0.012 & $<0.0001$ \\
\hline Fruit and vegetables (Yes/No) & 0.04 & 0.04 & 0.007 & 0.48 \\
\hline Skin color (white, mixed, black) & -0.001 & 0.83 & 0.014 & $<0.0001$ \\
\hline Smoking (Yes/No) & -0.026 & $<0.0001$ & -0.018 & 0.0006 \\
\hline Healthy diet score (quartile) & 0.0049 & 0.09 & -0.0006 & 0.73 \\
\hline No. of rooms in household & -0.0013 & 0.34 & -0.0055 & $<0.0001$ \\
\hline Cell phone (Yes/No) & 0.033 & $<0.0001$ & -0.011 & 0.25 \\
\hline \multicolumn{5}{|l|}{ City environmental variable } \\
\hline Mean no. rooms/household & -0.005 & 0.52 & -0.02 & 0.0004 \\
\hline Place for sports (Yes/No) & -0.16 & 0.01 & -0.12 & 0.05 \\
\hline$\%$ cell phone & 0.08 & 0.08 & 0.09 & 0.06 \\
\hline
\end{tabular}

${ }^{a}$ Values are weighted to adjust the sociodemographic distribution of the VIGITEL sample to that of the adult population of each city according to the 2000 Demographic Census. 
Table 4. Linear regression coefficient $(\beta)^{*}$ for body mass index with logarithmic transformation, adjusted for age only or for all associated factors with significance value below 0.10. ${ }^{a}$ Brazil, 2006. $(\mathrm{N}=49,395)$

\begin{tabular}{lcccc}
\hline $\begin{array}{l}\text { City cluster according to BMI } \\
\text { Difference in mean }\end{array}$ & Adjusted for age & $\begin{array}{c}\text { Men } \\
\text { Adjusted for all } \\
\text { factors }^{\mathbf{a}}\end{array}$ & $\begin{array}{c}\text { Women } \\
\text { Adjusted for age }\end{array}$ & $\begin{array}{c}\text { Adjusted for all } \\
\text { factors }^{\mathbf{a}}\end{array}$ \\
\hline 0.04 & - & - & 0.060 & 0.060 \\
0.03 & 0.057 & 0.039 & 0.049 & 0.052 \\
0.02 & 0.050 & 0.038 & 0.039 & 0.043 \\
0.01 & 0.042 & 0.031 & 0.034 & 0.032 \\
0 & 0.029 & 0.027 & 0.018 & 0.019 \\
-0.01 (São Luís) & & & Reference group & \\
\hline
\end{tabular}

* all values have $\mathrm{p}<0.01$

${ }^{a}$ Values are weighted to adjust the sociodemographic distribution of the VIGITEL sample to that of the adult population of each city according to the 2000 Demographic Census.

b Schooling, fruit and vegetable intake, smoking, healthy diet score, cell phone ownership, knowledge of place for physical activity, percent subjects with cell phone in city.

c Frequency of exercise, schooling, skin color, smoking, number of rooms in household, knowledge of place for physical activity, mean number of rooms per household in city

that women are more active in seeking to maintain a healthy diet than men. However, they may also result from information bias associated with current dietary norms. Our data show that BMI is lower among women of all ages. Although women are known to report lower weights and greater heights when compared to men, this error is thought to be small. ${ }^{5}$ In the 20022003 Household Budget Survey, ${ }^{\mathrm{a}}$ where weight and height were measured by the interviewer, higher prevalence of excess weight among men was also detected in most capitals, even though prevalence of obesity was higher among women.

The low explanatory power of the environmental variables investigated may also reflect the fact that differences in neighborhood of residence are actually more relevant to the issue of excess weight. A multilevel study conducted in the United States ${ }^{7}$ showed that distance from the place where food was purchased, rather than the fact of living in a poor neighborhood, was associated with obesity. Studies conducted with children ${ }^{4}$ and adolescents ${ }^{6}$ underscore the role of a safe environment in promoting physical activity and its beneficial effects on nutritional status.
In the present study, frequency of exercise among women seems to have been more important than duration. Associating the encouragement of physical activity at the individual level with presence of adequate spaces for its practice may prove a useful strategy for both men and women. Gender differences also indicate that gender-specific programs should be implemented aiming at reducing weight and preventing future gain.

In the present study, five-a-day $\mathrm{F} \& \mathrm{~V}$ intake was not associated with BMI among women, but showed a positive association with BMI among men. This suggests that simply increasing F\&V intake is not enough to displace the intake of more caloric, less healthy foods, which contribute to increasing BMI.

In conclusion, although there is a large discrepancy in prevalence of obesity among Brazilian cities, which is reflected by the large variation in mean BMI, important sex-related differences also exist. Individual variables and environmental characteristics of the city of residence were able to explain only a small fraction of the variation in BMI; however, presence of a place for physical activity remained negatively associated with BMI 


\section{REFERENCES}

1. Andrade RG, Pereira RA, Sichieri R. Consumo alimentar de adolescentes com e sem sobrepeso do Município do Rio de Janeiro. Cad Saude Publica. 2003;19(5):1485-95. DOI:10.1590/S0102311 X2003000500027

2. Brug J, van Lenthe FJ, Kremers SP. Revisiting Kurt Levin: How to gain insight into environmental correlates of obesogenic behaviors. Am J Prev Med. 2006;31(6):525-9. DOI:10.1016/j.amepre.2006.08.016

3. Cassady D, Jetter KM, Culp J. Is price a barrier to eating more fruits and vegetables for low-income families? J Am Diet Assoc. 2007;107(11):1909-15. DOI:10.1016/j.jada.2007.08.015

4. Farley TA, Meriwether RA, Baker ET, Watkins LT, Johnson CC, Webber LS. Safe play spaces to promote physical activity in inner-city children: results from a pilot study of an environmental intervention. Am J Public Health. 2007;97(9):1625-31. DOI:10.2105/ AJPH.2006.092692

5. Fonseca MJM, Faerstein E, Chor D, Lopes CS. Validade de peso e estatura informados e índice de massa corporal: estudo pró-saúde. Rev Saude Publica. 2004; 38(3):392-8. DOI:10.1590/S003489102004000300009

6. Gordon-Larsen P, Nelson MC, Page P, Popkin BM. Inequality in the built environment underlies key health disparities in physical activity and obesity. Pediatrics. 2006;117(2):417-24. DOI:10.1542/ peds.2005-0058

7. Inagami S, Cohen DA, Finch BK, Asch SM. You are where you shop: grocery store locations, weight, and neighborhoods. Am J Prev Med. 2006;31(1):10-7. DOI:10.1016/j.amepre.2006.03.019

8. Jaime PC, Machado FM, Westphal MF, Monteiro CA. Educação nutricional e consumo de frutas e hortaliças: ensaio comunitário controlado. Rev Saude Publica. 2007;41(1):154-7. DOI:10.1590/S003489102007000100021

9. Janssen I, Boyce WF, Sinpsom K, Pickett W. Influence of individual- and area-level measure of socioeconomic status on obesity, unhealthy eating and physical inactivity in Canadian adolescents. Am J Clin Nutrition. 2006;83(1):139-75.

10. Jeffery R, Drenowski A, Epstein LH, Stunkard AJ, Wilson GT, Wing RR, et al. Long-term maintenance of weight loss: current status. Health Psychol. 2000;19(1 Supl):5-16. DOI:10.1037/0278-6133.19.Suppl1.5

11. Levy-Costa RB, Sichieri R, Pontes NS, Monteiro CA. Disponibilidade domiciliar de alimentos no Brasil: distribuição e evolução (1974-2003). Rev Saude Publica. 2005; 39(4):530-40. DOI:10.1590/S003489102005000400003

12. Matheson FI, Moineddin R, Glazier RH. The weight of place: a multilevel analysis of gender, neighborhood material deprivation, and body mass index among Canadian adults. Soc Sci Med. 2008;66(3):675-90. DOI:10.1016/j.socscimed.2007.10.008

13. Monteiro CA, Conde WL, Popkin BM. Independent effects of income and education on the risk of obesity in the Brazilian adult population. J Nutr. 2001;131(3):881-6.

14. Monteiro CA, Moura EC, Conde WL, Popkin BM. Socioeconomic status and obesity in adult populations of developing countries: a review. Bull World Health Organ. 2004;82(12):940-6. DOI:10.1590/S004296862004001200011

15. Moura EC, Morais Neto OL, Malta DC, Moura L, Silva NN, Bernal R, et al. Vigilância de fatores de risco para doenças crônicas por inquérito telefônico nas capitais dos 26 estados brasileiros e no Distrito Federal (2006). Rev Bras Epidemiol. 2008,11(Supl 1):20-37. DOI:10.1590/S1415-790X2008000500003

16. Sichieri R, do Nascimento S, Coutinho W. The burden of hospitalization due to overweight and obesity in Brazil. Cad Saude Publica. 2007;23(7):1721-7. DOI:10.1590/S0102-311X2007000700025

17. Singh GK, Kogan MD, van Dyck PC. A Multilevel Analysis of State and Regional Disparities in Childhood and Adolescent Obesity in the United States. J Community Health. 2008;33(2):90-102. DOI:10.1007/ s10900-007-9071-7

This article underwent the peer review process adopted for any other manuscript submitted to this journal, with anonymity guaranteed for both authors and reviewers. Editors and reviewers declare that there are no conflicts of interest that could affect their judgment with respect to this article.

The authors declare that there are no conflicts of interest. 